\title{
Vanhuusiän syrjäytyminen pähkinänkuoressa - tuloksia ja politiikkasuosituksia ROSEnetistä
}

\author{
Päivi Topo, Elisa Tiilikainen, Marjaana Seppänen
}

Muutama vuosi sitten Gerontologia-lehdessä esiteltiin vastikään käynnistynyttä kansainvälistä Euroopan Unionin COST Action -rahoitteista tutkimusverkostoa ja sen puitteissa järjestettyä tutkijakoulua, joka käsitteli vanhuusiän syrjäytymistä (Mäkiniemi \& Tiilikainen 2017). Nyt kyseisen tutkimusverkoston, ROSEnetin, alkamisesta on kulunut yli neljä vuotta ja on aika koota yhteen verkoston antia. Ohjelman virallinen päätösseminaari järjestettiin Brysselissä maaliskuussa 2020 juuri ennen koronapandemian leviämistä, ja olimme siellä mukana julkistamassa verkoston kuudetta ja viimeistä tiivistelmäraporttia (Briefing Paper). Tässä kirjoituksessa luomme katsauksen raportin sisältöön ja muihinkin verkoston tuotoksiin. Toivomme kirjoituksen avaavaan uusia näkökulmia vanhuusiän syrjäytymisen ja eriarvoisuuden tarkasteluun sekä tarjoavan välineitä myös vanhojen ihmisten syrjäytymisen vähentämiseksi tehtävien toimien tueksi.

\section{ROSEnetin tausta ja sisältö}

ROSEnet-tutkijaverkoston nimi tulee sanoista Reducing Old Age Social Exclusion. Mielenkiinnon kohteena ovat siis syrjäytymisen ja eriarvoisuuden kysymykset vanhuudessa. Nuorten syrjäytymisestä käyty keskustelu on vakiintunut osaksi yhteiskuntapoliittista debattia, mutta harvemmin keskusteluissa esiintyvät syrjäytyminen ikääntyessä ja vanhuudessa.
ROSEnet-verkostoa luotsasivat sosiaaligerontologian professorit Kieran Walsh Irlannista ja Thomas Scharf Iso-Britanniasta. Tutkimusohjelman nelivuotisen rahoituskauden aikana verkosto järjestäytyi viiden eri teeman mukaisiksi työryhmiksi, joissa kirjoitettiin tutkimuskatsauksia ja politiikkasuosituksia vanhuusiän syrjäytymisestä. Viime keväänä julkaistu raportti kokoaa verkoston tuotoksia ja toimii linjapaperina, joka antaa suuntaa tulevaisuuden eriarvoisuustutkimukselle. Sekä verkoston että raportin päätavoite on ollut lisätä teoreettista ja empiiristä ymmärrystä iäkkäiden syrjäytymisen ilmiöistä ja vanhuuden aikaan liittyvästä syrjäytymisestä.

Vuosien 2016 ja 2020 välillä ROSEnetverkosto järjesti sarjan seminaareja, joissa kuultiin sekä tutkijoita että Euroopan tasolla toimivia politiikan tekijöitä ja iäkkäiden asioita ajavia kansalaisjärjestöjä. Osana verkostoa toimi tutkijakoulu, jota veti professori Marjaana Seppänen. Tutkijakouluja järjestettiin yhteensä neljä: Helsingissä, Camerinossa Italiassa, Ljubljanassa Sloveniassa ja Swanseyssa Walessa. Tutkijakouluihin osallistui sekä väitöskirjaettä postdoc-vaiheessa olevia nuoria tutkijoita eri puolilta maailmaa.

Nuorten tutkijoiden kansainvälisiä vierailuja tuettiin matka-avustuksilla ja osallistamalla heitä verkoston tapaamisiin erilaisten lyhyiden tutkimusesittelyjen ja nuorten tutkijoiden omien työpajojen merkeissä. Ohjelman alkuvaiheesta saakka mukana onkin ollut aktiivinen 
opiskelijayhteisö, joista monet ovat väitelleet tutkimusohjelman aikana. Yhteistyö verkoston tutkijoiden kesken on näkynyt myös erilaisissa tutkimusseminaareissa ja -tapahtumissa. Muun muassa gerontologian pohjoismaisessa kongressissa ja alan maailmanlaajuisissa kongresseissa on ollut useita ROSEnet-verkoston jäsenten yhteisiä symposiumeja.

ROSEnetin toiminnan käynnistyessä tehtiin video, jossa verkostossa mukana olevat tutkijat esittivät tiivistetysti näkökulmia vanhuusiän syrjäytymisen eri ulottuvuuksiin sekä niihin liittyviin ratkaisuihin. Video (https://www. youtube.com/watch?v=1TssdZpoyN0) on nähtävissä YouTubessa sekä englanniksi että suomeksi tekstitettyinä versioina. Videota on käytetty sosiaaligerontologian alan opetuksessa myös Suomessa.

\section{Syrjäytymisen moniulotteisuus}

ROSEnet-tutkijaverkoston keskeinen sanoma on ollut vanhuusiän syrjäytymisen moniulotteisuus. Sitä havainnollistavat erilaiset näkökulmat, joista käsin syrjäytymistä on ohjelman aikana tarkasteltu. Verkoston julkaisemissa raporteissa syrjäytymistä on käsitelty niin taloudesta, sosiaalisista suhteista, palveluista, kansalaisyhteiskunnasta kuin ajan ja paikan merkityksistä käsin (ks. http://rosenetcost.com/ knowledge-synthesis-papers/). Varsinaisia tiivistelmäraportteja on yhteensä kuusi, joista viisi ensimmäistä käsittelee syrjäytymistä kukin yhdestä ulottuvuudesta käsin ja kuudes kokoaa yhteen eri ulottuvuuksiin liittyviä kysymyksiä.

Verkoston alkuvaiheessa Kieran Walsh,Tom Scharf ja Norah Keating julkaisivat katsausartikkelin, jossa he kokosivat yhteen vanhuusiän syrjäytymistä koskevaa tutkimusta. Artikkelissaan Walsh ja kumppanit (2017) tarkastelivat syrjäytymisen määritelmiä, ulottuvuuksia ja niiden yhteen kietoutumista sekä syrjäytymisen seurauksia. Kirjoittajien mukaan vanhuusiän syrjäytyminen sisältää eritasoisia riskitekijöitä, prosesseja ja lopputulemia. Syrjäytymi- sen muodot ja vakavuusasteet vaihtelevat aikuisuuden elämänkulun aikana. Aikuiselämän aikana tapahtuvan syrjäytymisen moniulotteisuus, vaikutukset ja yleisyys kietoutuvat vanhuuden haavoittuvuuteen ja syventävät syrjäytymistä entisestään. Tämän seurauksena joidenkin ihmisryhmien tilanne entisestään huonontuu ja keinot parantaa heidän tilannettaan heikentyvät.

Walshin ja kumppaneiden (2017) mukaan vanhuuden syrjäytyminen johtaa eriarvoisuuteen mahdollisuuksissa kontrolloida omaa elämää ja tehdä valintoja. Eriarvoisuutta kohdataan resurssien jakautumisessa, ihmissuhteissa, vallan käytössä ja perusoikeuksien toteutumisessa. Nämä eriarvoisuudet heijastuvat ja toteutuvat naapurustoissa ja asuinalueilla, palveluissa, etuisuuksissa, taloudellisissa ja materiaalissa resursseissa, liikkumisessa, sosiaalisissa suhteissa, kulttuurisessa ilmapiirissä sekä yhteiskunnallisessa osallistumisessa. Tutkimusten valossa vanhuusiän syrjäytymisellä on vaikutuksia niin yhteiskuntiin, yhteisöihin kuin yksilöihin, minkä vuoksi siihen tarttuminen kaikilla tasoilla on tärkeää. Vuonna 2010 Euroopan komissio linjasikin ikääntyvien yhteiskuntien yhdeksi tärkeimmäksi haasteeksi vanhojen ihmisten syrjäytymisen vähentämisen (European Commission 2010).

Katsausartikkelin tulokset toimivat tärkeänä pohjana ROSEnet-verkoston työskentelylle, joka on sittemmin keskittynyt erityisesti seuraaviin viiteen syrjäytymisen ulottuvuuteen: taloudellinen, sosiaalisiin suhteisiin, palveluihin, yhteisöihin ja paikkaan sekä kansalaisuuteen liittyvä syrjäytyminen. Kunkin teeman sisällä verkoston tutkijat ovat tarkastelleet, millaisia syrjäyttäviä rakenteita sekä sosiaalisia ja kulttuurisia käytäntöjä vanhuusiän syrjäytymisen taustalla on. Kuviossa 1 on kuvattu eri ulottuvuuksiin sisältyviä aihealueita. Ulottuvuudet kietoutuvat monin eri tavoin yhteen yksittäisen ihmisen tai ihmisryhmän elämässä. Moniulotteisuus kertoo myös siitä, että tarvitaan laaja-alaista yhteiskuntapolitiikkaa estämään syrjäytymistä ja lieventämään sen vaikutuksia hyvinvointiin. 


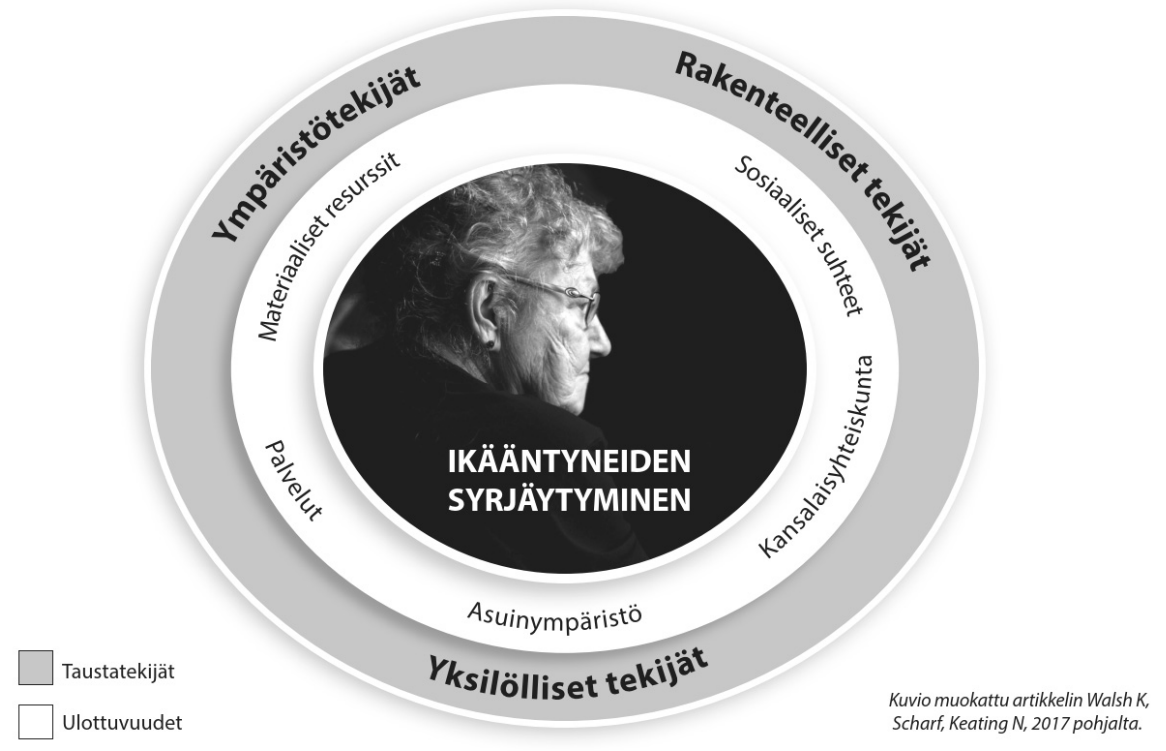

Kuvio 1. Iäkkäiden sosiaalisen syrjäytymisen ulottuvuudet.

Seuraavaksi tarkastelemme tiivistetysti kuviossa esillä olevaa viittä syrjäytymisen ulottuvuutta ja ROSEnet-verkoston pääviestiä sekä yksittäisiin teemoihin että syrjäytymisen moniulotteisuuteen liittyen (ks. Walsh ym. 2020).

\section{Taloudellinen syrjäytyminen}

Taloudellisella syrjäytymisellä tarkoitetaan tilannetta, jossa yksilön tulot eivät riitä ihmisarvoiseen elämään. Teemaa käsittelevä työryhmä pohjasi työnsä erityisesti Amartya Senin kyvykkyyttä käsittelevään teoriaan. Senin mukaan ei riitä, että tarkastellaan vain sitä, mitä henkilö omistaa, vaan pikemminkin on tarkasteltava sitä, mitä kukin yksilö tai ihmisryhmä voi tehdä tai varsinaisesti tekee. Materiaalisten resurssien ohella huomiota on kiinnitettävä yksilön mahdollisuuksiin ja tarpeisiin. Eri ihmiset ja ihmisryhmät voivat saada samoilla resursseilla aikaan eri asioita. Tähän vaikuttavat fyysiset ja henkiset voimavarat (esim. vammaisuus, sairaudet), sosiaalisen päöoman saatavuus (esim. ilman sukulaisia tai läheisiä olevat), kulttuurinen pääoma (esim. digitaidot), ympäristötekijät (esim. harva asutus, turvaton lähiö), erot sosiaalisissa asemissa (esim. työkyvyttömyyseläkkeellä vs. työssä olevat) sekä eriarvoisuus julkisten hyödykkeiden ja palveluiden saamisessa (ml. sote-palvelut, oppiminen).

Työryhmän mukaan erilaiset taloudelliseen syrjäytymiseen johtavat polut ja niiden vaikutukset ikääntyvien elinolosuhteisiin ja osallistumismahdollisuuksiin tulisi ottaa systemaattisesti huomioon köyhyyden ja syrjäytymisen vähentämiseen tähtäävissä politiikkatoimissa. Taloudellisesta eriarvoisuudesta johtuvat heikot materiaaliset resurssit heijastuvat laajasti myös muille syrjäytymisen osa-alueille. Esimerkiksi Suomessa käynnissä olevat työmarkkinaja eläkepolitiikan uudistukset asettavat etusijalle rahoituksen kestävyyden eivätkä kiinnitä riittävästi huomiota sosiaaliturvaverkkojen tarjoamiseen niille, joiden tilanne heikkenee muutosten myötä. Tällainen lähestymistapa voi pahentaa eriarvoisuutta ja vahvistaa vanhuuden syrjäytymisriskiä. 
Ikääntymiseen liittyviä talouspoliittisia toimenpiteitä suunnitellessaan EU:n jäsenvaltiot tarvitsevatkin koordinoitua lähestymistapaa, jossa otetaan huomioon köyhyyden lievittäminen osana ikääntyvän väestön elämänlaadun parantamista esimerkiksi terveydenhuollon, asumisen, ympäristön ja yhteiskunnallisen osallistumisen näkökulmasta. Tutkijoita työryhmä kehottaa kiinnittämään entistä enemmän huomiota taloudellisen ja materiaalisen huonoosaisuuden kysymyksiin sekä tarkastelemaan työmarkkina- ja eläkejärjestelmiä erityisesti taloudellisesti prekaareissa asemissa olevien näkökulmasta.

\section{Syrjäytyminen sosiaalisista suhteista}

Syrjäytyminen sosiaalisista suhteista liittyy tilanteisiin, joissa ihmisellä ei ole riittävästi merkityksellisiä ja läheisiä sosiaalisia suhteita, sosiaalisia verkostoja eikä sosiaalista tukea tai mahdollisuuksia, jotka edesauttaisivat hänen osallistumistaan laajempaan yhteiskuntaan.

Olemassa oleva tutkimus osoittaa, että sosiaalisten kontaktien puuttuminen (yksinolo) tai kokemus yhteyden puutteesta (yksinäisyyden tunne) aiheuttaa haitallisia seurauksia ihmisen terveydelle ja hyvinvoinnille. Välillisesti syrjäytyminen sosiaalisista suhteista voi johtaa myös lisääntyneen palvelun tarpeen kautta lisäkustannuksiin yhteiskunnalle. Yksinolon ja yksinäisyyden taustalla on sekä yksilö-, yhteisöettä yhteiskunnallisen tason tekijöitä, ja niihin voi sisältyä kriittisiä elämäntapahtumia ja siirtymiä ihmisen elämässä. Sosiaalisista suhteista syrjäytymisen tarkastelussa tarvitaankin kokonaisvaltaista näkökulmaa, jossa otetaan huomioon erilaiset, niin rakenteelliset kuin yksilölliset tekijät, yksilön tämänhetkinen elämäntilanne sekä aiemmat kokemukset elämänkulun varrelta. Tunnistamalla ja huomioimalla nämä tekijät voidaan tukea ihmisen osallisuutta sosiaalisista verkostoista ja vähentää yksinäisyyden tunnetta.
ROSEnetin sosiaalista syrjäytymistä koskevan työryhmän viesti politiikkasuositusten muodossa on, että politiikan tasolla tulisi aktiivisesti edistää sellaisia toimintatapoja, joissa muun muassa palvelujärjestelmän eri osa-alueilla huomioidaan riittävästi erilaiset sosiaaliset tarpeet. Tämän lisäksi tulisi kehittää erilaisia ehkäiseviä strategioita ja interventioita, joilla voidaan tukea sosiaalisia suhteita elämänkulun eri vaiheissa ja kriittisten elämäntapahtumien yhteydessä. Jatkuva tiedon tuottaminen sosiaalisista suhteista syrjäytymisen yleisyydestä, taustatekijöistä ja vaikutuksista hyvinvointiin on myös tärkeä lähtökohta politiikalle ja palveluiden järjestämiselle.

\section{Syrjäytyminen palveluista}

Tutkimuksissa on todettu, että ikääntyneiden palvelunkäyttäjien osallisuus palvelujen kehittämisessä on tärkeää palveluista syrjäytymisen vähentämiseksi (esim. Olsson ym. 2019). Syrjäytyminen palveluista liittyy palveluiden järjestämisen tapaan, saavutettavuuteen ja kustannuksiin sekä siihen, että iäkkäät eivät pääse vaikuttamaan itseään koskeviin palveluihin ja niiden suunnitteluun ja toteutukseen. Palveluista syrjäytyminen kytkeytyy usein pienituloisuuteen, syrjässä palveluista sijaitsevaan asuinpaikkaan, yksinasumiseen, sosiaaliseen eristäytymiseen ja matalaan koulutustasoon. Taustalla vaikuttaa usein piiloon jäävä ikäsyrjintä lainsäädännössä ja resurssien jaossa (ks. Kröger ym. 2019 iäkkäiden hoivaköyhyydestä).

Palvelujen ulkopuolelle jäämiseen on tärkeää puuttua ja varmistaa tasapuolisuus palvelujen saatavuudessa ja käytössä. Palveluinfrastruktuurin asianmukaisuus tulisi huomioida kaikilla keskeisillä palvelualoilla, kuten pitkäaikaishoidossa, liikenteessä sekä tieto- ja viestintätekniikkaan perustuvissa palveluissa. Ikääntyneiden ääni erilaisissa suunnittelu- ja täytäntöönpanoprosesseissa parantaa palvelujen tarkoituksenmukaisuutta ja edistää sitä, että pal- 
velut vastaavat tarpeisiin ja helpottavat jokaiselle kuuluvaa oikeutta osallisuuteen yhteiskunnassamme.

Erityisen tärkeää on ottaa huomioon ympäristöön ja alueisiin liittyvien tekijöiden vaihtelu. Tällaisia tekijöitä ovat esimerkiksi väestön tiheys, maantieteellinen sijainti sekä urbaanin ja maaseutuympäristön erot ja yhtäläisyydet. Tärkeää on myös tarjota informaatioteknologian käyttöön liittyvää koulutusta ja tukea, sillä digiosaamisen rooli palveluista syrjäytymisen ehkäisyssä kasvaa jatkuvasti. Ennen kaikkea palveluiden suunnittelussa on kuitenkin pyrittävä inklusiivisuuteen ja helppokäyttöisyyteen.

\section{Paikkaan ja yhteisöihin liittyvä syrjäytyminen}

Yksi ihmisen elämänkulun tärkeistä asioista on paikka tai paikat, jotka kytkeytyvät elämän eri vaiheisiin; suurin osa ihmisistä haluaa ikääntyä tärkeäksi kokemassaan paikassa (Andrews \& Phillips 2005). Myöhemmän elämänvaiheen kokemukset kytkeytyvät usein aiempia elämänvaiheita enemmän ympäristön ja asuinalueiden sosiaalisiin ja fyysisiin ulottuvuuksiin. Ikääntyneiden asuinpaikat vaikuttavat syrjäytymisriskiin. Ne voivat suojata syrjäytymiseltä tai lisätä syrjäytymisen riskiä.

Asumiseen liittyvän syrjäytymisen politiikkasuosituksissa avainasioita ovat esteettömyys ja saavutettavuus. Syrjäytymisen ehkäisyssä keskeinen tavoite tulisi olla liikkumisen ja liikkumiskyvyn edistäminen, sillä sen avulla ihmiset voivat jatkaa mieleistään elämää kotona, osana paikallisia yhteisöjään ja osallistuen niiden elämään. Ikääntymismuutoksia voi kompensoida ympäristöä muokkaamalla. Jos näin ei tehdä, voivat toimintakyvyn muutokset ja lievätkin kognitiiviset heikentymiset vähentää iäkkäiden osallisuutta.

Tärkeää on tuottaa sellaisia monimuotoisia mahdollisuuksia, jotka vastaavat vanhojen ihmisten yksilöllisiin tarpeisiin. Näitä voivat olla myös uudet asumisen muodot, kuten erilaiset jaetut asumisen ratkaisut ja sukupolvien välisen yhteisen asumisen mahdollisuudet. Jotta sosiaalinen osallisuus asuinympäristöissä on mahdollista, julkisten tilojen tulee olla sekä sosiaalisesti että fyysisesti saavutettavia, houkuttelevia ja turvallisia. Kaikkien toimien pitää perustua ymmärrykseen erilaisten tarpeiden kirjosta.

\section{Kansalaisuuteen liittyvä syrjäytyminen}

Kansalaisuuteen liittyvä syrjäytyminen vähentää ikääntyvien ihmisten ja ryhmien vaikutusmahdollisuuksia, ja heidän näkökulmansa jää kuulematta. Lisäksi syrjäytyminen kansalaisuudesta yhdenmukaistaa iäkkäiden kokemuksia yhteiskunnan institutionaalisista rakenteista, politiikoista ja yhteisöistä. Se voi olla jäämistä syrjään kansalaistoiminnasta, tai se voi tarkoittaa erilaisia esteitä osallistumiselle poliittiseen ja vapaaehtoistoimintaan. Tähän liittyy myös symbolisia ulottuvuuksia, kuten ikäsyrjintää.

Abramsin ja Swiftin (2012) mukaan Euroopassa yli 300 miljoonaa ihmistä on kokenut ikäsyrjintää. Euroopan sosiaalitutkimuksen (ESS) vuosina 2008-2009 kerätty aineisto (vastaajina 15 vuotta täyttäneet ja sitä vanhemmat ikäryhmät 27 maassa) osoitti, että 35 prosenttia vastanneista oli kokenut epäoikeudenmukaisesta kohtelua iän perusteella. Tämä oli paljon enemmän kuin niiden osuus, jotka olivat kokeneet syrjintää sukupuolen tai rodun perusteella.

ROSEnetin työn pohjalta todetaan, että ikäsyrjintä on yleisin syrjinnän muoto. Se vaikuttaa ajatteluun, kieleen, päätöksentekoon ja osallistumismahdollisuuksiin. Osallistuminen oman yhteisön tai laajemmin yhteiskunnan päätöksentekoon voi vaatia resursseja, joita iäkkäillä on vähän. Osallistumisen mahdollisuudet ovat erityisen pieniä, jos henkilöllä on samanaikaisesti muitakin syrjäyttäviä tekijöitä omassa elämässään.

Suosituksena iäkkäiden syrjäytymistä vähentävälle politiikalle on, että päätöksentekoon tarvitaan ikävaikutusten arviointia. Tässä tar- 
vitaan sekä päätöksentekijöiden että työntekijöiden koulutusta julkisen sektorin kaikilla tasoilla. Vanhojen ihmisten tulee olla mukana politiikan muotoilussa ja toteuttamisessa. Hallitusten tulee ottaa vastuulleen toimet, joiden avulla voidaan lisätä tietoisuutta ikäsyrjinnästä sekä ikääntymisen monimuotoisuudesta. Ennen kaikkea tärkeää on lisätä ymmärrystä siitä, että monet vanhat ihmiset kokevat syrjäytymistä useilla yhteiskunnan areenoilla.

\section{Syrjäytymisen moniulotteisuus}

Syrjäytymisen riskit ja ilmiöt kietoutuvat toisiinsa. Vanhuudessa tapahtuva syrjäytyminen tai sen uhka on usein yhteydessä tapahtumiin ja tekijöihin elämänkulun varrella. Esimerkiksi keskimäärin heikompi fyysinen terveys voi liittyä fyysisesti hyvin kuormittavaan työhön. Eläkeläisköyhyys puolestaan voi koskettaa erityisesti niitä ikääntyneitä, joilla on ollut hyvin

\section{Kirjallisuus}

Abrams D, Swift H. Ageism doesn't work. Public Policy Aging Rep 2012;22(3):3-8. https://doi.org/10.1093/ppar/22.3.3

Andrews GJ, Phillips DR, ed. Ageing and place: perspectives, policy, practice. London: Routledge, 2005.

European Commission. Combating poverty and social exclusion 2010 edition: a statistical portrait of the European Union 2010. European Commission, 2010. Internet: https://ec.europa.eu/eurostat/documents/3217494/5723553/KS-EP09-001-EN.PDF/beb36abc-ff29-48a0-851832b64ad73ca5 (viitattu 4.4.2021).

Kröger T, Van Aerschot L, Puthenparambil M. Ikääntyneiden hoivaköyhyys. Yhteiskuntapolitiikka 2019;84(2):124-34. https://www.julkari.fi/handle/10024/137957

Mäkiniemi L, Tiilikainen E. Tutkijakoulusta ymmärrystä vanhuusiän syrjäytymiseen. Gerontologia 2017;31(1):71-5. pieni palkka tai pitkiä työttömyysjaksoja ennen eläköitymistä. Vanhuuserityinen syrjäytyminen ja sen riski korostuu viimeisten elinvuosien aikana (taustalla heikentynyt terveys, riippuvuus muiden avusta, sairauskulut) sekä läheisten vakavien sairastumisten ja kuolemien yhteydessä. Sukupolvispesifi syrjäytyminen liittyy tällä hetkellä erityisesti digisyrjäytymiseen ja englannin kielen vallitsevaan asemaan.

ROSEnetin tutkimukseen pohjautuvien politiikkasuositusten pääviesti oli, että vanhojen ihmisten syrjäytymisestä ilmiönä tarvitaan ymmärrystä. Tarvitaan myös halua vaikuttaa ilmiöön ja toteuttaa politiikkatoimia, joilla voidaan ennaltaehkäistä syrjäytymistä ja lievittää sitä.

\section{Yhteydenotto:}

Päivi Topo, VTT, dosentti

Ikäinstituutti

paivi.topo@ikainstituutti.fi

g

Olsson T, Samuelsson U, Viscovi D. At risk of exclusion? Degrees of ICT access and literacy among senior citizens. Inf Commun Soc 2019;22(1):5572.

https://doi.org/10.1080/136911

8X.2017.1355007

Walsh K, Scharf T, Keating N. Social exclusion of older persons: a scoping review and conceptual framework. Eur J Ageing 2017;14(1):81-98. https://doi.org/10.1007/s10433-016-0398-8

Walsh K et al. ROSEnet Cost Action CA 15122: Multidimensional social exclusion in later life. Briefing paper and A roadmap for future research and policy collaboration, 2020. Internet: http:// rosenetcost.com/wp-content/uploads/2017/01/ cost_rosenet_actionpolicy6_web.pdf (viitattu 4.4.2021). 